\title{
The Collapse of the Romantic Illusions in the Story of Bulat Okudzhava "Be Healthy, Schoolboy"
}

\author{
Pozina Marina \\ Slavyansk-on-Kubani Library, Cuban State University, Krasnodar, Russia
}

\author{
Email address: \\ kub_mvp@mail.ru
}

\section{To cite this article:}

Pozina Marina. The Collapse of the Romantic Illusions in the Story of Bulat Okudzhava "Be Healthy, Schoolboy". History Research. Vol. 7, No. 2, 2019, pp. 32-37. doi: 10.11648/j.history.20190702.12

Received: July 24, 2019; Accepted: September 9, 2019; Published: October 10, 2019

\begin{abstract}
The story "Be healthy, scholar" - a unique phenomenon of the Russian Soviet literature of the twentieth century. The heroes of the war of prose and poetry of the time was not supposed to think about the proximity of death, of hunger on the front line, about the confusion in the orders, feelings of loneliness and hopelessness. Authors of books on military subjects portrayed brave people, ideological fighters against fascism. Writer Okudzhava departed from the prescribed literature templates and showed war as seen through the eyes of yesterday's schoolboy. 60 years of the last century were a period of "thaw" not only in the socio-political life of the country, but also in literature. For a little while, but strict censorship was lifted and the opportunity to write honestly about his own military experience. After all, the story is autobiographical Okudzhava: it is about him - yesterday the boy, who was dressed in a soldier's greatcoat and sent to war. Tale of how the scholar wants to live and afraid of death, ready to give their lives for their country, but would prefer, if possible, not to give up. Brutal military weekdays saved the young hero of the story psevdoromanticheskogo nonsense, revealing the truth - in war there is nothing great. "War can not be great" - openly declared Okudzhava. Only a convinced pacifist courage allowed the writer to express a point of view is radically different from the conventional. Research task article - evaluate the novel by Bulat Okudzhava "Be Healthy, scholar" as an attempt to debunk the literary romantic myths about the war in the Russian literature of the twentieth century. author of the article believes thatBulat Okudzhava's story reflects the realities of war and is indispensable in the study of front-line prose. The focus of the paper, the author focuses on the fact that people in war is left alone with his weaknesses, fears, pain.
\end{abstract}

Keywords: Okudzhava, The Collapse of Romantic Illusions, War Story "Bless You, The Student", The Story of the War, The Military Reality, Prose About the War

\section{Introduction}

Okudzhava belongs to a generation of "the sixties", so called writers and poets, whose names became known to the reading audience in the 60 years of the twentieth century. It was a special time in the history of Soviet literature, when the yoke of censorship eased and for the authors the opportunity to publish works that before they wrote only "on the table", as no publisher and no magazine would not publish them.

There are coincidences in life when someone's personal birthday suddenly becomes important for the whole country. This happened with the war poet Bulat Okudzhava, whose birthday is May 9. As a child he was so sorry that he was born in than not noticeable day. As could be predicted, the time will come and the Victory Day and the birthday will be celebrated at the same time! The war, known to the world as World War II, has left no trace, and a scar in the soul of the future bard, composer and writer. In 18 years, public-spirited young man was drafted into the army, and after two months of preparation, in October 1942, was sent to the Transcaucasian Front. Yesterday's student has become a mortar in a cavalry regiment of the 5th Guards Don Cossack Corps. 16 December of the same year under the Mozdok Okudzhava was wounded and sent to hospital.

That these events devoted to autobiographical novel "Bless you, scholar." Okudzhava said: "I have always maintained that there was no" great "war. There was a war, a massacre. Bloody massacre". Seeing the inside of war, experiencing its hardships, Okudzhava wrote about the war not as all - "for show and lyrically." 
Many literary critics have repeatedly appealed to the story "Be healthy, scholar." This work is still a matter of debate, so it is not typical for Soviet prose. It does not make heroes and romantic illusions of yesterday's schoolboy breaking on harsh military truth. The writing of this article was made possible through the study of literary works S. S. Boyko, L. I. Lazareva, V. A. Zaytseva, MR Gizatulina, D. L. Bykova, MA Gureeva devoted to how all creativity Bulat Okudzhava, and he and his autobiographical novel "Bless you, scholar."

\section{Okudzhava and Autobiographical Prose About the War}

Referring to the work of Bulat Okudzhava and try to understand why the author was necessary to write prose about the war. Many readers generally know Okudzhava as a bard and poet, but he was also a novelist. He wrote prose from an early age, they were mostly long novels, filled with the romance of the revolution. It was a kind of tribute to youthful maksimalizmu. Vot as the poet himself says in the pages of "Literary Gazette" in 1997 for the June 18 article Okudzhava "still ahead" we read, "But it draws to write prose, and not just fiction, but about himself memories, seventeen soldiers with bandy legs in the winding, which is sent to the front. Fifteen years after the war, I somehow thought himself ridiculous and miserable, although all remember quite clearly. He wrote with pleasure. I had not thought about the literary laurels. I read a few chapters of your friends in the "Literary Gazette". Everyone was nice to me. So I wrote, especially without straining after all, nothing should have been invented, refined, creating a "prose". He wrote memoirs. It's all. However, when I drew his frontline youth, no, no, and I remember how sublime lesson trenches that Nekrasov, the Simonov, the Bulls, the Baklanov, Bondarev then, all the terrible, tragic, heroic, bloody. I remember, and I have openly write about the bastards fool who for some reason do not want to die on the battlefield, and want to live, live...

No internal censors did not correct me, because I do not write for the press, and it is clear to anyone. Of course, for those who lived in those years. Finally, I put an end to this. I feel that some very vague storyline has been completed. Hundred pages on a typewriter. The first prose in my life! Not "War and Peace" and "The Captain's Daughter", but this is my life! Well, although there is no positive hero, and that all are miserable and ridiculous that nothing "heroic" seems to be happening, but it was so! I'm not lying. [3]

From under his own bonnet escaped censorship that for many years was kept in the recesses of the soul - the truth about the war through the eyes of yesterday's schoolboy. "Thaw" 60-ies of XX century liberated the people lifted the taboo on the truth and fear of strict censorship.

Suddenly you can write about his own military experience, honest, but unheroic, ever disappoint him in all sorts of extremes romance? Maybe, deep down, he admitted that this thing will be printed. Because it had to print - it's any consolation for many. Anyone who wants to live and afraid of death, and considers it his crime. Those who are willing to give their lives for their country, but would prefer, if possible, not to give up.

Now we see that there is a need of the author to write about his war experiences. "The attempt to rethink the events that took place almost two years ago (at the time) was the written Bulat Shalvovich v1960-1961's story" Be healthy, scholar [9]) Okudzhava had the opportunity to write about their own military experience, honest, but not heroic. Personal front-line experience ever cured him of extreme romance, showing the ugly wrong side of military life. He wrote not for the press, but rather to cure his own soul, he transferred to the paper's own painful memories of confusion and helplessness that he felt at the forefront. His character - a home boy, remembering the warmth and comfort, and a keener sense of the injustice of the war and the inability of a man to influence what is happening. [9]

"Your spirited horse can not do anything. You're at a glance, all the bullets in one," says Bulat Okudzhava in on the history. "I dedicate my sons Igor and Anton. It's not an adventure. The fact is, as I fought. They wanted to kill me, but I was lucky. I do not know, whom I thank for it. And, perhaps, there is no one" [2].

The author wrote "Shkolar" very quickly - within two months.

"The story was quite unlike anything written about the recent war, perhaps it is because it was written without any hope of publication, as if for internal use. There was not anything heroic, moreover, the author does not hesitate, he wrote that it was terrible," the war [6].

He wrote it with a sense of liberation from old fears, shame, war nightmares that haunted him still.

This story turned out, strictly speaking, not a military operation, because there is almost no attacks, battles and heroic resistance, but there is a languid expectation of the battle, as well as rain and cold, endless transitions from one position to another grueling military work and a sense of perfect losses. History is written simply, we can say, it is written in plain language. Something felt in her, due to her work with Remarque "On the Western Front, with no changes." Okudzhava same growing sense of absurdity of what is happening, without releasing the hero story for a minute. There is no heroism, and where it may come, if the boy from Arbat yard can not be reconciled with the fact that he is mortal, and, moreover, is doomed.

The hero stories Okudzhava not even his name - he was just a schoolboy. He is one of many local boys, torn out and thrown to the front line, who do not know anything and do not know how to fight. The student does not understand what is happening around you: "The second time crying here in Mozdok steppe. I wear a very important package to the regimental commander. The devil knows where he is, commander of the regiment! Sand hills alike. Night. And I am the second day at the forefront. And for the nonfulfillment of tasks - execution. And I'm eighteen years ". [2]

Here every man for himself and no one says anything scholars, perhaps because the battalion commander and he 
does not understand do not understand anything? All the time he wanted to sleep and eat, his actions automatically, so the war turns a man into his arms. "I met you, the war. I have big bruises on his hands. In my head the noise. I want to sleep. You want to take me from everything to what I'm used to? Do you want nawchit me obey you implicitly? Creek commander - run, perform, stunning bark "Yes!", To fall, to crawl, go to sleep on the go. The rustle of mine - to be buried in the ground, digging her face, arms, legs, whole body, without fear, without thinking. Pearl pot of soup - to allocate gastric juice, get ready to rumble, saturate, wipe the spoon on the grass. Friends die - swarming the grave, a rash of land, shoot sky mechanically, three times"' [2].

Hero of the Russian literature was supposed to be a brave man and a romantic, ideological fighter against fascism. Okudzhava showed the opposite direction of the war - with all the irrationality of what is happening to her. He showed the absolute uncertainty of the soldier and his natural fear of death. The boys were eager to front, not knowing where to go, and knowing nothing about the poor supply of the army, the hostility of the local population about the possible death by a stray bullet. Romantic illusions become reality pretty quickly.

The writer was able to accurately describe the amazing inner monologue of a young soldier - scholars:...? "Help me Help me, help me I do not want to die A little piece of lead in my heart, in my head - and my hot body and will no longer be hot..? Let the pain be. Who says I'm afraid to suffer? At home, I much fear. House. And now I've found out everything, I tried everything. Is not it enough to know so much? I even tenth grade not finished. Help me Please help me. I'm not talking about love. to hell with it, with love. I agree not to love. At the end to ntsov, I loved. It is enough for me, for that matter. I have a mother. What is it ?. And you know how sweet it is when my mother stroked her hair? I have not had time to break the habit of. I've never been anywhere else, for example, I was not in Valdai In the end, I need to see what it is necessary for the Valdai eventually, someone wrote: "... And the bell - a gift of Valdai..?... "But I can not write these lines. Help me, help me. I will give everything. To end. I'm going to shoot at the Nazis, as a sniper, I will fight with tanks, will go hungry, unable to sleep, suffer... "" [2] At the head of the hero is confusion thoughts, but out of this mess, it is clear one -. He wants to live, he ready for anything, but to live.

Schoolboy does all that have to be a soldier, charged automatically drives, something responsible plotter, but his inner monologue with himself much more verbose and emotional. Remembering his classmate, Eugene, he again heard her words: "I'm sorry you guys. Do you think you fight so easily? War needs a silent, somber soldiers. Warriors. No need to make a noise. I feel sorry for you. And you... "She nodded at me," you do not know anything else other than reading books. "And there - death, death... And she really loves these very young as you" [2].

Yes, it was a different war, not the one shown in the feature film and newsreel shots. And it's not even talked about the romantic heroism of the brave, proudly staring at the face of the enemy soldiers and sailors, partisans and workers with campaign posters, which was disappointed in wonder. [9]

The war, which was eager 17-year-old Bulat, was dirty and terrible work on the implementation of which depended on your life and fulfilling that it was necessary to understand clearly what you mean it (the work) do - to defend their homeland, receive awards and stars on the shoulder straps, you earn to life or serving povinnost. Eto was a great war in which he had no place either as a hero-order bearer, either as a victim, as if the inexorable Moloch not dignify it to their attention, as if it never existed at all. [10]

So what was this war for Okudzhavy?

It is possible that the story "Be healthy, scholar," and was an attempt to answer this question (for Bulat Shalvovich in the first place) [ten]

First of all it was a war with himself, meanwhile, some wanted to be, and in what was in fact, despite the fact that this conflict began long before 1941 and continued after the great victory.

Tale of Bulat Okudzhava "Bless you, the student," was a sensation of Soviet literature, about the war, they have not been contacted - without pathos and glorification bright romance. "Bless you, the student," I joined the flow front of prose.

Tale sparked opposition officials, but has found readers love. Front-line writers do not know firsthand about the person in the war, "they tell us about the experience, which still have their burns." Thus, many of the characters autobiographical; First-person narrative, the selected works of V. Astafev in the "Star" (1960), K. Vorobiev in the "Scream" (1961), B. Okudzhava in "scholar" - sounds organic. "In the literary context of the central hero prose front opposed to the socialist - realist - a warrior-hero." The charge was heartbreaking, had the character of ideological demagoguery. Workers would hope that society at the turn of the 1950 s and 1960 s, full of tragic memory of the war, which would not have escaped his misery, will angrily reject a real attempt to degenerate. In the eyes of the people of the soldiers was a real hero, fascism winner, savior of the Fatherland. However, this does not mean that for the reader it was equal stilts hero-warrior, allegedly unknown with a sense of fear or the need for self-preservation. The audience sympathized with the author hero of the story, "they all wanted the truth" [4]

\section{Publication of the Story "Be Healthy, Scholar" in "Tarusa Page"}

Published in the anthology "Tarusa Pages" story "Be healthy, scholar" was almost immediately criticized.

You could not just write that there is nothing in the almanac of the Soviet. Okudjava was selected as the primary target. This is one of the paradoxes of his biography: in "Tarusa page" was enough of another revolt, but to criticize him, it was recognized that the described events "happen." 
The dispute about the present would be fraught with danger, the same substantive discussion, which mortally afraid of the then society, not only the top, I stress, but also a society that is already adapted to the half and was afraid too sharp turns. Okudzhava was the perfect target, because he wrote about the war - and the war, as we recall, was the last of a consensus value of the entire Soviet myth: here we converge and dissidents, and nomenclature. And suddenly there is a text in which the heroic completely absent, and weakness, fear, longing for home is filled with all artistic space! [one].

Exploring the history of creation and publishing, we see that the story Okudzhava was uncomfortable for many. Why? The answer to this question is contained in the story, though not obvious:

"When in the eighth grade, we had a falling out with Vladimir Anilova, I first called out to him:

Let's get together! - And I was scared. But we went to school. And comrades surrounded us. First, he hit me on the arm.

Oh, like that?! I screamed and pushed him on the shoulder. Then we have long blamed each other, not daring to attack. And suddenly I felt funny, and I told him:

Listen, I'll give you a mile...

Give, give! He shouted, and put out his fists.

"Either you give me." Bleed. Well, what's the difference?

He suddenly calmed down. We shook hands on all the rules. But then the friendship is gone." [one].

Okudzhava hero discovered his alien, so to speak, nature and it is not surprising that the friendship was not there. He walked away from the canons of not only Soviet, but also thieves, courtyard, male world - struggle prevented the rules. Now, if they are really united with Volodya Anilova, friendship would be restored as if nothing would. Just think, Miles cleared each other. This is not the collapse of the friendship, and her confirmation she will be stronger with the massacre. But to see the meaninglessness of "clashes" and "fights" - means to show its true nature, that is, not to behave in the worst (the most respected), and at best, a human being. And that, you know, not forgiven.

And now we see what criticized "scholar"? For the truth of which was made to keep quiet - the famine and drinking in the army, about the lack of rights of soldiers, of the existence of women in war, hostility of local residents to the soldiers. History has destroyed the illusion, and it has not been forgiven Okudzhava.

Okudzhava after the story "Be healthy, scholar," attributed to the most serious sins. "The story came to light in" Tarusa pages ", which were condemned by a special resolution of the Bureau of the Central Committee of the Communist Party of the RSFSR. In the preparation of the decision was active notorious Yegor Ligachev. In a previous decision of the note prepared by the two Central Committee departments "threatening or abusive essay Okudzhava said:" The protagonist of the story and his comrades look frankly cynical, Loose, cowardly people deprived high feelings of love for the motherland, loyalty to the cause of socialism, of the will to fight against fascism, then there are all those fine qualities, which gave the invincible strength of our fighters... [10].

"Heroes it does not say the words of love for the country, which is usually utters in newspaper essays and mediocre novels: they seem to him false and unchaste. But he went to the front as a volunteer, that very clearly reveals his attitude to what is happening, his mood, although he says his actions in humorous tones, not wanting him as heroes. And hatred for the fascist invaders hero utters speech, but did not understand what was in his heart, if he has experienced many humiliating discomforts due to the lost spoons, refused to take the trophy - it makes him disgusted! Generally high in the story, as it was in the real war, when shipped, ingrained in everyday life, in an incredibly heavy frontline life, depressing is no less than the fear of death. [9] "Pages Tarusa" with the story "Be healthy, schoolboy 'was published edition 75000 copies! Holiday flared, but then came, as it became known that on orders from above the main part of the edition was destroyed in the bud, and the remaining 30,000 were allowed to sell off the shelves. And no copies - in stores or in the library..." [3].

But is it possible to remove from circulation the truth? They read the story then, in the sixties, they read it now, wondering sincere thoughts of the hero stories, and hear the pure sound coming from my childhood. And it infuriates those who betray themselves, and those who kept them, encouraging and comforting. Those who read the story "Bless you, the student," admired the courage of the author, tells a different truth about the war.

Okudzhava not forgiven him the truth about the war, described in the story and to the restructuring it has not been published in our strane. Za abroad as the story was published repeatedly. In Poland under the title "Do you still you live" in December 1962, and later in France under the name of "Spoon". Story published in many languages in many countries. First separate edition story was published in Russian in 1987.

\section{Conclusion}

As the author of the research objectives was defined task to evaluate the story of Bulat Okudzhava "Be Healthy, scholar" ka literary attempts dispelling the romantic myths about the war in the Russian literature of the twentieth century. Story not published, were forbidden. We see all scared outdoor antiwar pathos of the story. It destroys the romantic illusion taught to see priglyadnuyu not always the truth. The story was a war, ringworm one size fits all. "However, in the years that describes Okudzhava in the story" Be healthy, scholar, "the time to overcome the psychology of" cogs "time independent decisions, whichprice of life or death. One way or another, in one degree or another have experienced this many. "We were taught time" is one of the songs of Okudzhava, very important recognition. difficult ordeal time really was a very important school, taught to see the truth. And so it became for many the time overcoming the Stalinist propaganda myths deeply penetrated 
the public consciousness, finding common sense, realistic view of what is happening. This process is precisely defined its deep essence of our well-known historian Michael Hefter, behind which was a difficult experience, and in war, spawned spontaneously arising "de-Stalinization". Duhovny experience many soldiers later became a psychological base XX Party Congress, helped to crush not only the recent idols and heroes, but also to nurture their totalitarianism. [10] Okudzhava could not forgive what he showed in the story romantic story epiphany yesterday's schoolchildren. "It was ruthless, but many schools open their eyes. The hero of "Be Healthy, scholar" threw the psevdoromantichesky nonsense whom he fed with a pioneering school years and who was not as harmless as it may seem at first glance, because it helped dupe, irresponsibility, gave birth to "peresortitsu" false and true values. At the front, at the time of testing the strength of the soul, on a genuine, not decorative and poster patriotism, he was the strongest vaccinated against injustice and demagogy, inhumanity, which will then be protected from infection by viruses of these diseases in their later contemporary mutations. [10] Thus, as a result of the study author commended product. Story "Be healthy, scholar" has played a huge role in the development of the literary process of the XX century, the time of thaw, shattered illusions about the war, before described in literature, writing and reading of the novel became for many an irreversible process of overcoming the Stalinist propaganda myths about the war.

Author of the article believes that Bulat Okudzhava's story reflects the realities of war and is indispensable in the study of front-line prose. Questions about the role and importance inRussian literature of the twentieth century the impact of the story on the world view of today's youth are like raasmatrivatsya perpektivnoe direction of further study of the novel by Bulat Okudzhava "Be Healthy, scholar".

The author expresses his gratitude to the students who during the study after reading bvli Write a novel by Bulat Okudzhava.

"Bless you, scholar," "Bless you, the student." - this is a book about ordinary people, everyday, "casual" war. I believe that the book is worth reading for those who would like to see the war through the eyes of others, to look at it not as used to be looked upon knightly deeds, vile treachery, scary adventure. This story is for those who want to see how they lived and fought the common people during the most terrible war. (Svetlana Ivanova, student Philological Faculty)

"I was reading an autobiographical novel by Bulat Okudzhava" Be healthy, schoolboy! ". In it he frankly tells how, inexperience and stupidity, he took the whistle of German bullets to birds singing, I leaned to hear from the shelter, and almost died. As he once paid off a cigarette on the sole and very frightened, thinking that sparks are scattered from him caused a fire of the German mortars, as well as many other things that can be read in the book.

"When I started reading this book, I thought that I would see the most common story about the war, but it was not so. There are no speeches about love of country and hatred of the Nazis, no feats and special glorification, it was the other - about the difficult life at the front, which is no less oppressive than the fear of being injured or ubitym. O yesterday's students, who, in spite of everything, We remained in the war - they loved, friends, joke and laugh with each other. This book is written simply and movingly. And it's worth reading to find out how young people feel when they got into the war. "

\section{References}

[1] Bykov, DL Okudzhava. - M.: Young Guard, 2009.- 594 p. (Lots of great people).

[2] Okudjava, B. S. Cheers, pupil / B. Sh // Okudzhava Arbat yard: lyrics, prose / B. Sh Okudzhava. - M.: Veche, 2006.- S. 241309.

[3] Okudjava, B. S. More ahead (1997) - electronic resource / B. Sh.

[4] Okudzhava // - URL: https://imwerden.de/pdf/okudzhava_vse_eshche_vperedi.pdf

[5] Boyko, SS "I met you, the war"...: heroes frontline lyrical novel and student Okudzhava / SS Boyko // Bulletin of the RSU. Ser.. Philology. Literary criticism and folklore. 2010. N 2 (45). S. 173-184.

[6] Kondratovich AI Man at war: (Notes criticism) / AI Kondratovich // New World. 1962. N 6. S. 216-228.

[7] Gizatulin, MR Okudzhava. All life - in one line / MR Gizatulin. M.: AST: OGIZ, 2019.- 528 p.: Silt (Great Period).

[8] Prose Bulat Okudzhava in the mirror critics - electronic resource // URL: https://globuss24.ru/doc/proza-bulataokudzavy-v-zerkale-kritikov.

[9] Gora M. Okudzhava. Just to know and live with it / M. Gureev.-M.: AST: OGIZ, 2019.- 240 p.: Silt (Great Period).

[10] Lazarev, LI Living is not believed to be alive....: Notes on the literature devoted to the Great Patriotic War / LI Lazarev - M.: MIC, 2007.- 416 p.

[11] Okudjava, B. From school to the front / Okudzhava. B.-M.: Algorithm 2019.- 240 p.: Series (My War).

[12] Pozina, MV The collapse of the romantic illusions in the story Okudzhava "Be healthy, scholar '/ MV Pozina // Questions of literature. 2018. №4. S. 209-214.

[13] Kulchitskaya, N. N. Pravda war - the truth about the person (Formation of the spiritual powers of man in literature Great Patriotic War) / NN Kulchinskaya // text, context, intertext Collected articles on materials International scientific conference «XIV Vinogradov reading. Contributing Editor IA Birich, VA Kokhanova, AY CHelnokova. 2016. pp 124-134.

[14] Shaffert, E. A. Kommunikativnye practice in a series of books for children / EA Shaffert // Vestnik Novosibirsk State University. Series: History, Philology. 2016. 15. T. number 6. S. 130-142.

[15] Chen, D. Translation and study of creativity B. Sh. Okudzhava in China / D. Chen // International postgraduate Gazette. Russian language abroad. Number 2. 2019. pp 46-50. 
[16] Bernstein, IE Children's literature of the Soviet era: Problems commenting / IE Bernstein // Baby chteniya. 2016. 10. T. number 2. pp 105-12. 